How to cite this article:

Soon, A. L., Derashid, C., \& Bidin, Z. (2020). DTPB as a better voluntary tax compliance predictor - A comparison study. Journal of Business Management and Accounting, 10(2), 31-56.

\title{
DTPB as a Better Voluntary Tax Compliance Predictor - A Comparison Study
}

\author{
Ang Leng Soon, Chek Derashid* \& Zainol Bidin \\ Tunku Puteri Intan Safinaz School of Accountancy (TISSA), Universiti Utara \\ Malaysia, Sintok, Kedah, Malaysia
}

Received: 19/4/2020 Revised: 29/6/2020 Accepted: 17/7/2020 Published: 15/11/2020

\begin{abstract}
Tax administrators have been trying to maximise its voluntary tax compliance rate where e-filing system has been the preferable compliance tool by taxpayers in submitting their income tax return forms. Despite the effort to provide better services to taxpayers, the heterogeneous taxpayers in Malaysia face difficulties in extracting information and tax knowledge that would require assistance or advice from other sources, like their peers and mass media, while some may have financial difficulties. This comparative study proposes to utilise the multidimensional model of Decomposed Theory of Planned Behaviour (DTPB) that incorporates general tax knowledge, mass media referent, and ability to pay as addition to the original DTPB model. The findings showed that general tax filing knowledge, mass media referent, and ability to pay have significant influence on intention to comply with tax laws. However, perceived usefulness, perceived ease of use, compatibility, and self-efficacy were found to be not significant when the DTPB model was adopted. Nevertheless, it is advantageous to use the DTPB model that provides predictiveness and explanation toward understanding voluntary tax compliance behaviour. This model is useful as a guide for improving voluntary tax compliance rates while promoting the advantages of using e-filing system as the preferable tool for compliance.
\end{abstract}

Keywords: Voluntary tax compliance intention, theory of reasoned action (TRA), theory of planned behaviour (TPB), Decomposed Theory of Planned Behaviour (DTPB).

Corresponding Author

E-mail: chek@uum.edu.my 


\subsection{Introduction}

Tax compliance is very complex with many countries face serious problems toward maximising tax compliance rate (Oh \& Lim, 2011). In providing efficient, convenient, and effective services, tax administrators have been improvising to accommodate taxpayers with the ease of submitting income tax return voluntarily. Many countries had adopted the Self-Assessment System (SAS) with Canada and United States as the earliest countries implementing in 1910s, Ireland in 1988, and New Zealand in 1988, also including Asian countries like Japan in 1947, Pakistan in 1979, and Indonesia in 1984 (Okello, 2014). However, it is still difficult for many tax administrators worldwide to motivate taxpayers toward voluntary compliance (James \& Alley, 2004). Hence, tax administrators provide the options for taxpayers to comply voluntarily by way of manual or electronic forms.

Although taxpayers have the option to file their income tax return forms either manually or electronically, many tax administrators focus on the usage of e-filing systems as the main tool to increase voluntary tax compliance rates. The e-filing system provides an efficient and effective way for taxpayers to voluntarily file their income tax return form conveniently. In 2017, there were a total of 5,536,265 registered active individual taxpayers (IRBM, 2018) with only 2,742,701 filing their tax return forms (Tax Operation Department, IRBM), of which 96.8\% filed online through the e-filing system. The compliance rate was just $49.54 \%$ in terms of timely income tax return form submission, which is far from the maximum compliance rate. Even with the establishment of Section 112 of ITA 1967 as a serious offence under Schedule 2 of Anti-Money Laundering, Anti-Terrorism Financing and Proceeds of Unlawful Activities Act 2001 (AMLATFPUAA 2001) (IRBM, 2013) with a fine less than RM5 million or less than five years imprisonment or both, has not facilitate IRBM with an increase in compliance rate. Hence, compliance determinants should be further examined. Moreover, extensive studies on e-filing user acceptance are still insufficient to understand the behavioural issues of e-filing system, which is more important than just technological acceptance (Hung, Chang, \& Yu, 2006).

Hence, the aim of this study was to predict voluntary tax compliance intention among individual taxpayers in Malaysia. To examine the factors that would affect individual taxpayer's intention to comply voluntarily toward filing income tax returns on timely basis, constructs were decomposed based on the Decomposed Theory of Planned Behaviour (DTPB) (Taylor \& Todd, 1995b). In the study by Taylor and Todd (1995a), attitude, subjective norm, and perceived behavioural control are decomposed into multidimensional constructs to provide better intention predictive power. This study focused on decomposing the attitude construct with general tax knowledge, perceived usefulness, perceived ease of use, and compatibility, the subjective norm construct with peer influence and mass media referent, and perceived behavioural construct with selfefficacy, facilitating conditions, and ability to pay; towards voluntary tax compliance intention. 
The objective of this study was to identify predictive power as well as the effect size of the competing theories utilised for tax compliance. Subsequent section discusses the use of variables in the study by first investigating other behaviour intention theory, such as TRA, TPB, and DTPB. The purpose of this paper was to investigate the predictive power of each of these theories in predicting voluntary tax compliance.

\subsection{Literature Review}

\subsection{Theory of Reasoned Action}

Theory of Reasoned Action (TRA) was founded by Ajzen and Fishbein (1980) in order to provide a solution for the limitations of the Expectancy Value Theory (EVT) originating from the field of psychology. The purpose of this theory is for the prediction of human behavioural intention by providing a prediction of attitude and behaviour. This theory suggested that an individual's behaviour is determined by intentions which are influenced by individual's attitude toward the behaviour and subjective norms surrounding the behaviour performance (Ajzen \& Fishbein, 1980). As defined by Fishbein and Ajzen (1975, p. 201), behavioural intention is "an individual's subjective probability that he or she will perform a specified behaviour". The diagram below is an illustration of the Theory of Reasoned Action (TRA):

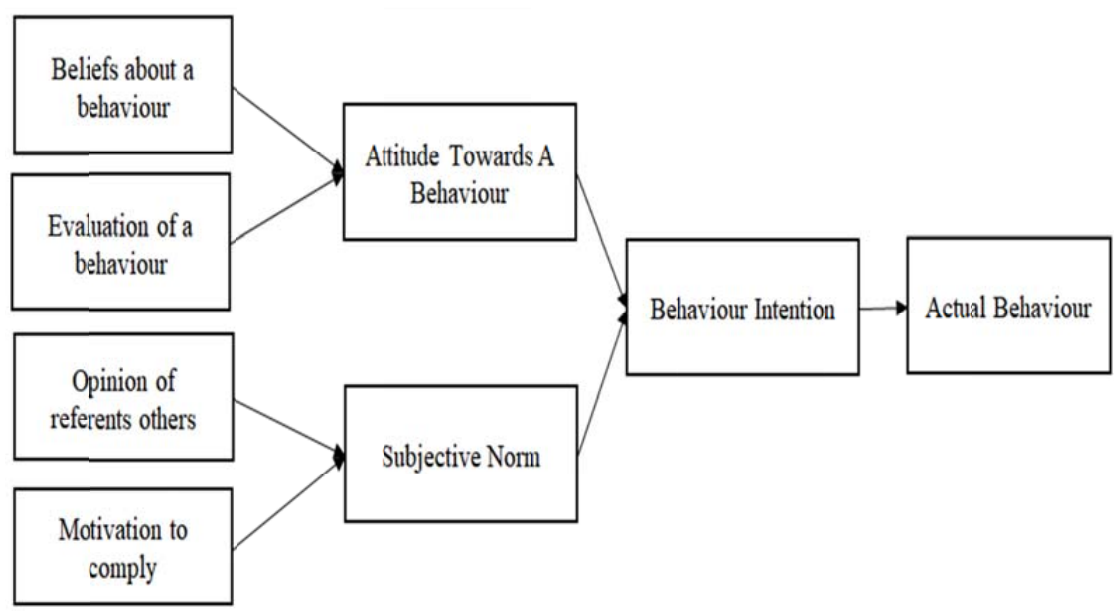

Figure 1: Theory of Reasoned Action (TRA)

Source: Ajzen and Fishbein (1980) 
As indicated in the diagram above (Figure 1), both constructs of attitude and subjective norm are seen as unidimensional measurements of beliefs as well as the evaluation of a behaviour. This theory is especially helpful in explaining intentions in certain settings, such as studies on AIDS-preventive behaviour (Fisher, Fisher, \& Rye, 1995), brand loyalty (Ha, 1998), coupon usage (Shimp \& Kavas, 1984), condom usage (Kashima, Gallois, \& McCamish, 1993), fast food restaurant patronage decisions (Bagozzi, Wong, Abe, \& Bergami, 2000), recycling behaviour prediction (Goldenhar \& Connell, 1992), teen sexual behaviour (Gillmore et al., 2002), user acceptance of system usage (Liker \& Sindi, 1997), as well as consumer motivation (Fitzmaurice, 2005). This theory is still fully adopted in recent studies on Goods and Services Tax (GST) compliance (Bidin \& Mohd Shamsudin, 2013), cyberbullying (Doane, Kelley, \& Pearson, 2016; Doane, Pearson, \& Kelley, 2014), green information technology (Mishra, Akman, \& Mishra, 2014), and digital piracy (Woolley, 2015).

Despite the many contributions of this theory in explaining behaviour intentions, it is not without limitations. Both internal and external controlled factors are not accounted for in this theory. Examples like resources constraints and facilitating conditions are excluded. This theory may only be applicable under rational, thoughtful, and systematic behaviour (Kang, Hahn, Fortin, Hyun, \& Eom, 2006) where under incomplete volitional control it is not influential. Hence the Theory of Planned Behaviour (TPB) was proposed as an alternative to providing a better explanation of an individual's behaviour intentions.

\subsection{Theory of Planned Behaviour (TPB)}

TPB was an extension to the Theory of Reasoned Action (TRA) that was adapted and adopted to explain and predict individual's behaviour toward tax filing (Hastuti, Suryaningrum, Susilowati, \& Muchtolifah, 2014; Hsu \& Chiu, 2004b; Hung et al., 2006). Based on TPB, an individual's action will be determined by their perception of control and intention, with individual's intention being determined by attitude toward a behaviour including subjective norms as well as perceived behavioural control (Ajzen, 1991; Fishbein \& Ajzen, 1975). As indicated in the diagram below (Figure 2), the constructs of attitude, subjective norm, and perceived behavioural control are seen as unidimensional measurements of beliefs as well as the evaluation of a behaviour.

Numerous studies revealed the ability and applicability of TPB in various field of studies, which are useful toward understanding and predicting new technology acceptance (Ajzen, 2001). This suggests that TPB model is effective in explaining intention and behaviour of individuals toward adopting new technologies. As such, several past studies that adopted TPB model includes online tax filing (Ramayah, Mohd. Yusoff, Jamaludin, \& Ibrahim, 2009), IS usage behaviour of post-merger employee 


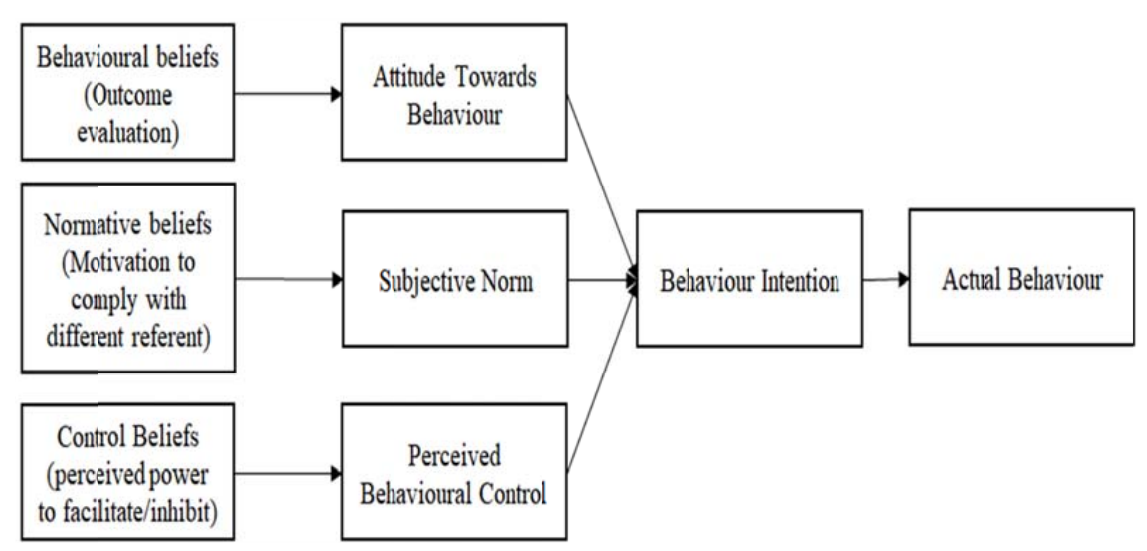

Figure 2: Theory of Planned Behaviour

Source: Ajzen (1991)

(Huang \& Chuang, 2007), telemedicine technology acceptance by physicians (Chau $\& \mathrm{Hu}, 2001$ ), electronic brokerage services acceptance (Bhattacherjee, 2000), internet banking acceptance (Khalil, 2005), adoption and usage of computer resource centre (Taylor \& Todd, 1995b); and electronic service continuance (Hsu \& Chiu, 2004b) as to cite a few examples.

\subsection{Decomposed Theory of Planned Behaviour (DTPB)}

The Decomposed Theory of Planned Behaviour is the extension by Taylor and Todd (1995a) that was derived by decomposing the belief structure of the TPB model. The constructs of attitude, subjec tive norm, as well as perceived behavioural control were decomposed into detailed belief constructs. All three main variables of TPB were decomposed to obtain clearer and easily understandable relationships of the three belief constructs. Furthermore, the decomposed constructs provide stable belief structures that are manageably relevant and can be easily applicable across variety of settings, which enables them to pinpoint the specific factors influencing adoption and usage (Lau, 2004).

Several past studies examined DTPB model's validity toward understanding behavioural intention (Hsu \& Chiu, 2004a; Tao \& Fan, 2017; Taylor \& Todd, 1995a). Tao and Fan (2017) modified the DTPB model to study user's intention on distance-based electronic toll collection services in Taiwan. However, there is limited tax research that utilise DTPB model in the studies. In Taiwan, Hung et al. (2006) utilised the DTPB model 
to study taxpayer's online tax filing and payment system (OTFPS) usage intention. They found that all nine antecedents of perceived usefulness, trust, perceived risk, perceived ease of use, compatibility, external influences, interpersonal influence, selfefficacy and facilitating condition except for personal innovativeness have significant influence towards users' acceptance. The adoption of DTPB model in their study were able to explain $72 \%$ of taxpayers' behavioural intention. It was also found that the extended model provides higher total variance as compared to previous models studied by Mathieson (1991), and Venkatesh, Morris, Davis, and Davis (2003), including the original DTPB model by Taylor and Todd (1995a). Meanwhile in Surabaya City, Indonesia, Hastuti et al. (2014) adapted the DTPB model with several extensions and modifications in their study in relation to usage of e-filing system to file annual tax income. They found that DTPB increases the predictive power toward predicting e-filing behavioural intention.

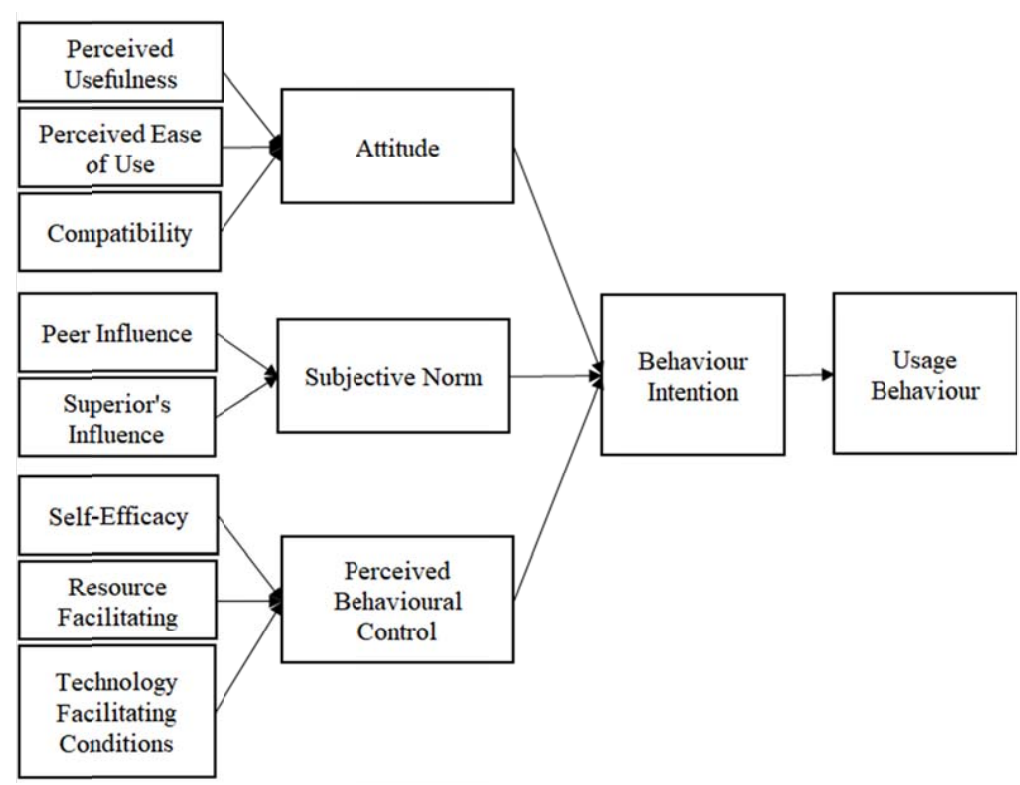

Figure 3: The Decomposed Theory of Planned Behaviour (DTPB) model

Source: Taylor and Todd (1995a)

This study examined the voluntary tax compliance intention via e-filing system using a comprehensive theoretical model based on the decomposed TPB. Several rationales for using DTPB as the underpinning theory for this study are explained as follows. As the intention to comply voluntarily with tax laws using e-filing system 
is not entirely under the taxpayers' control, the presence of constraints inhibits the taxpayers' intention to perform a behaviour as well as the actual behaviour itself. Furthermore, taxpayers' voluntary tax compliance behaviour can be affected by peer influence and mass media referent where subjective norm is an important behavioural determinant. Using mass media as referent, the taxpayers may have some basic tax knowledge toward complying tax laws voluntarily. However, there are some factors like self-efficacy, facilitating conditions, and ability to pay that may have impact on compliance behaviour. Nevertheless, DTPB is an appropriate model that provides a strong managerial implication for practitioners (Hastuti et al., 2014). Hence, this model can effectively elicit taxpayer's compliance behaviour in the submission of income tax form via e-filing system through their salient belief structure while attaining factors that are stable, easy understandable, and managerially relevant.

\subsection{Methodology}

In comparing the behavioural theories, changes were made based on each theoretical framework. The DTPB model decomposed its constructs into several dimensions, while the other competing theories focuses on unidimensional constructs. As such, hypotheses were developed according to each original theoretical framework with measurements that were either grouped into each compatible construct or tested accordingly based on each decomposed dimension and construct. In this study, 12 hypotheses were developed based on the DTPB model. However, measurement items of the dimensions in DTPB model were grouped accordingly to test each variable of the TRA and TPB models. This was to obtain results based on similar measurement items for theoretical comparisons.

Practically, it is tough to obtain responses from individuals that are non-compliant (Mckerchar, 2008). However, measures were taken to obtain responses from individuals working in Klang Valley. This study focused on individuals with employment income taxpayers who work in offices located in Klang Valley. In Malaysia, the total active registered taxpayers with employment income is 5,536,265 (IRBM, 2018). This study involved multi-layer clustered respondents where taxpayers were first defined as those working in large offices in Klang Valley. Then, only those individuals with Monthly Tax Deduction (MTD) in their payslip were selected. For the purpose of this study, 20 offices were identified for survey where softcopy of the survey form was provided to the representative of each office that was assigned to distribute among 100 employees with MTD in their payslip.

In line with the popularity and escalation of web-based survey usage (Sax, Gilmartin, \& Bryant, 2003), this study utilised the online survey. The online survey provides no 
significant biasness as compared to face-to-face interviews (Lindhjem \& Navrud, 2011). Multi-layered cluster sampling was used to obtain a total number of 311 respondents. Before proceeding with the full-scale data collection, a pilot study was conducted in order to ascertain that the questions asked in the survey did indeed answer or address the research objectives stated. The pilot study was done as an Exploratory Factor Analysis (EFA) procedure in SPSS. After satisfying the criteria of validity and reliability for the pilot study, a new set of data was collected for further Confirmatory Factor Analysis (CFA). The data collected were then keyed into SPSS and further analysed in Smart PLS 3.2.8. The subsequent sections describe the results of the findings.

The scales adapted for this study were from previous literature as well as the Inland Revenue Board of Malaysia (IRBM) website. The table below contains scale items obtained from past studies that were used in this study:

Table 1

Scales Adapted

\begin{tabular}{lclc}
\hline Constructs & $\begin{array}{c}\text { Total } \\
\text { items }\end{array}$ & Sources & Cronbach $\boldsymbol{\alpha}$ \\
\hline Intention (INT) & 3 & Taylor \& Todd (1995a) & 0.91 \\
$\begin{array}{l}\text { Attitude (ATT) } \\
\text { General Tax Filing Knowledge }\end{array}$ & 4 & Taylor \& Todd (1995a) & 0.85 \\
(GTFK) & 8 & IRBM website FAQ's & NA \\
Perceived Usefulness (PU) & 8 & Taylor \& Todd (1995a) & 0.68 \\
Perceived Ease of use (PEOU) & 6 & Davis (1989) & 0.94 \\
Compatibility (COMP) & 6 & Taylor \& Todd (1995a) & 0.82 \\
Peer influence (PI) & 6 & Taylor \& Todd (1995a) & 0.92 \\
Subjective Norm (SN) & 4 & Taylor \& Todd (1995a) & 0.88 \\
Mass media referents (MMR) & 9 & Md Husin \& Ab Rahman & \\
& & (2016); Harrison (2009) & 0.70 \\
$\begin{array}{l}\text { Perceived Behavioural Control } \\
\text { (PBC) }\end{array}$ & 3 & Taylor \& Todd (1995a) & \\
Self-efficacy (SE) & & Taylor \& Todd (1995a) & 0.85 \\
Facilitating control (FC) & 6 & Taylor \& Todd (1995b); & 0.78 \\
& & Venkatesh, Chan, \& Thong & \\
Ability to pay (ATP) & 6 & Bidin \& Md Idris (2009) & 0.90 \\
\hline
\end{tabular}

The conceptual framework of this study is as follows (Figure 4). 


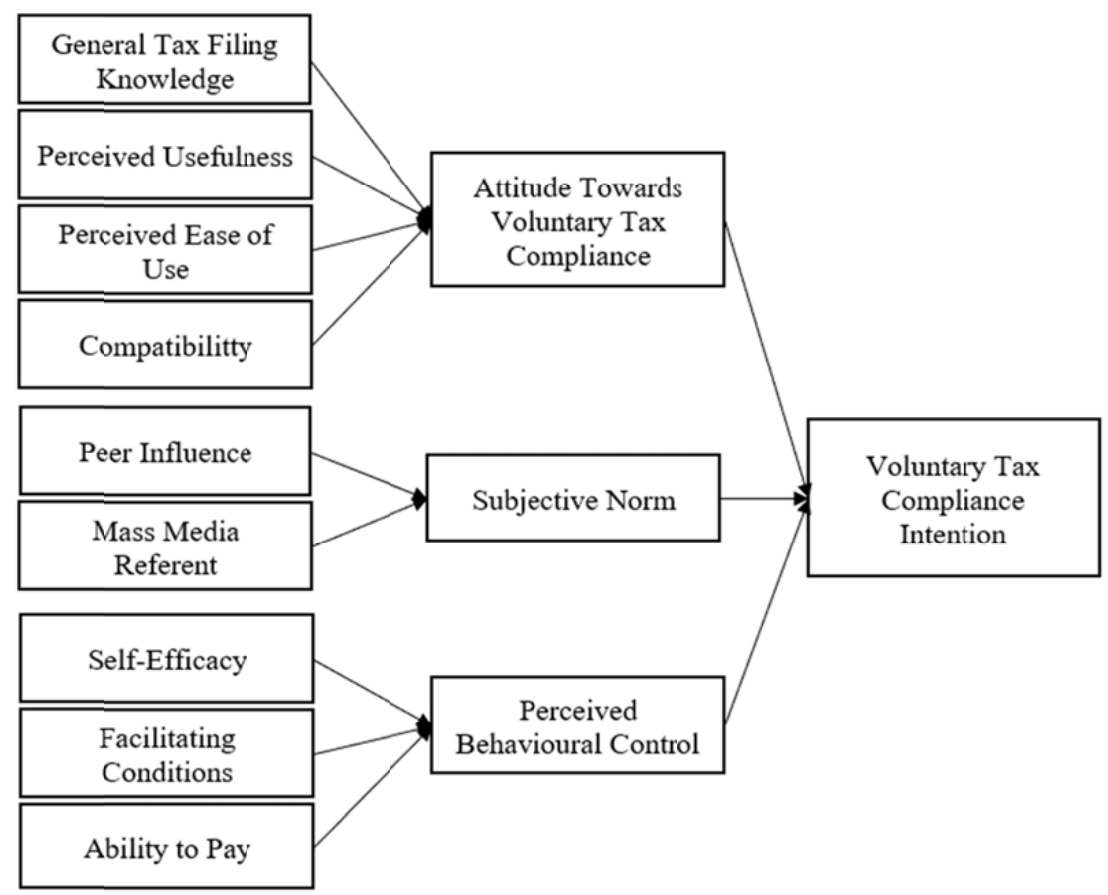

Figure 4: Conceptual framework

Below (Table 2) represents the hypotheses of this study.

Table 2

Research hypotheses summary

\begin{tabular}{cll}
\hline Hypothesis & Hypothesised Effect & \multicolumn{1}{c}{ Past Studies } \\
\hline H1 & GTK -> ATT & $\begin{array}{l}\text { Loo et al. (2010); Choong \& Wong (2011); } \\
\text { Mohd Tallaha et al. (2014) }\end{array}$ \\
H2 & PU -> ATT & Davis (1989); Taylor \& Todd (1995a) \\
H3 & PEOU -> ATT & Davis (1989); Taylor \& Todd (1995a) \\
H4 & COMP -> ATT & Taylor \& Todd (1995a); Mathieson (1991) \\
H5 & PI -> SN & $\begin{array}{l}\text { Wartick \& Rupert (2010); Damayanti (2012); } \\
\text { Mohdali \& Pope (2012) }\end{array}$ \\
\hline
\end{tabular}




\begin{tabular}{|c|c|c|}
\hline Hypothesis & Hypothesised Effect & Past Studies \\
\hline H6 & MMR -> SN & $\begin{array}{l}\text { Bhattacherjee (2000); Hsu and Chiu (2004a); } \\
\text { Md Husin et al. (2016) }\end{array}$ \\
\hline H7 & SE -> PBC & $\begin{array}{l}\text { Bandura (1986); Ajzen (1991); Taylor \& Todd } \\
\text { (1995a); Bhattacherjee (2000) }\end{array}$ \\
\hline H8 & $\mathrm{FC}->\mathrm{PBC}$ & $\begin{array}{l}\text { Bandura (1986); Ajzen (1991); Taylor \& Todd } \\
\text { (1995a); Bhattacherjee (2000) }\end{array}$ \\
\hline H9 & ATP $\rightarrow$ PBC & Hite (1997); Bidin \& Md Idris (2009) \\
\hline H10 & ATT -> INT & $\begin{array}{l}\text { Ajzen (1991); Taylor \& Todd (1995a); } \\
\text { Bhattacherjee (2000); Mathieson (1991) }\end{array}$ \\
\hline H11 & $\mathrm{SN}->\mathrm{INT}$ & $\begin{array}{l}\text { Ajzen (1991); Taylor \& Todd (1995a); } \\
\text { Bhattacherjee (2000); Mathieson (1991) }\end{array}$ \\
\hline H12 & $\mathrm{PBC}->\mathrm{INT}$ & $\begin{array}{l}\text { Ajzen (1991); Taylor \& Todd (1995a); } \\
\text { Bhattacherjee (2000); Mathieson (1991) }\end{array}$ \\
\hline
\end{tabular}

\subsection{Results and Findings}

Since this study only focused on employment sourced income only, both respondents with business sourced income and those without MTD deductions were excluded from the collected data. As such, there were five respondents with employment and business income and three respondents without MTD deductions in their payslips, thus they were removed from the data pool. After removing these respondents, a total of 303 valid responses were used for further analysis. The software used for the data analysis process was SPSS and Smart PLS 3.2.8.

The majority of respondents were aged between 35 and 44 (30\%). There were no respondents for the 15-24 and $>65$ age categories as it was assumed that they are either still students or retired. From the 303 valid responses received, $73 \%$ were married and have a bachelor's degree $(60.4 \%)$. The total number of respondents in the private sector was $46.9 \%$. From this, $71 \%$ only get their salary from employment. The respondents mostly filed their income tax via personal computer (52.8\%) and laptop (35\%). The respondents' demographic details are summarised in Table 3.

The scales used for this study had to be first tested for reliability and validity. As indicated in the table below, the scales recorded the reliability and validity above the threshold limit. The composite reliability for all scales were between 0.895 and 0.955 , all of which are above the 0.7 threshold. The AVE values were all above the threshold of 0.5 (between 0.571 and 0.974 ). 
Table 3

Demographic Profile

\begin{tabular}{|c|c|c|c|}
\hline Details & Category & Frequency & Percentage \\
\hline \multirow[t]{7}{*}{ Age } & $15-24$ & 0 & 0.0 \\
\hline & $25-34$ & 55 & 18.2 \\
\hline & $35-44$ & 91 & 30.0 \\
\hline & $45-54$ & 87 & 28.7 \\
\hline & $55-64$ & 70 & 23.1 \\
\hline & $>65$ & 0 & 0.0 \\
\hline & Total & 303 & 100 \\
\hline \multirow[t]{4}{*}{ Marital Status } & Single & 64 & 21.1 \\
\hline & Married & 221 & 73.0 \\
\hline & Divorced & 18 & 5.9 \\
\hline & Total & 303 & 100 \\
\hline \multirow{6}{*}{$\begin{array}{l}\text { Highest level of } \\
\text { education }\end{array}$} & High School & 2 & 0.7 \\
\hline & Diploma/Certificate & 55 & 18.1 \\
\hline & Bachelors & 183 & 60.4 \\
\hline & Masters & 57 & 18.8 \\
\hline & Ph.D./Doctorate & 6 & 2.0 \\
\hline & Total & 303 & 100 \\
\hline \multirow{6}{*}{$\begin{array}{l}\text { Household income } \\
\text { per month }\end{array}$} & $<$ RM5,000 & 0 & 0.0 \\
\hline & RM5,001 - RM10,000 & 55 & 18.1 \\
\hline & RM10,001 - RM15,000 & 72 & 23.8 \\
\hline & RM15,001 - RM20,000 & 85 & 28.1 \\
\hline & $>$ RM20,001 & 91 & 30.0 \\
\hline & Total & 303 & 100 \\
\hline Category of & Private Sector & 142 & 46.9 \\
\hline \multirow[t]{7}{*}{ Employment } & $\begin{array}{l}\text { Government Linked Companies } \\
\text { (GLC) }\end{array}$ & 10 & 3.3 \\
\hline & Government Servant (Under & 124 & 40.9 \\
\hline & Public Service Pension Scheme) & & \\
\hline & Department/ Agencies Under & & \\
\hline & Government Ministries (Without & 27 & 8.9 \\
\hline & Public Service Pension Scheme) & & \\
\hline & Total & 303 & 100 \\
\hline
\end{tabular}




\begin{tabular}{|c|c|c|c|}
\hline Details & Category & Frequency & Percentage \\
\hline \multirow[t]{6}{*}{ Sources of Income } & Salary from Employment only & 215 & 71.0 \\
\hline & Combination of Salary \& Other & 88 & 29.0 \\
\hline & $\begin{array}{l}\text { Non-Business Income (rental, } \\
\text { commission, etc.) }\end{array}$ & & \\
\hline & Combination of Salary \& & 0 & 0.0 \\
\hline & Business Income & & \\
\hline & Total & 303 & 100 \\
\hline \multirow{3}{*}{$\begin{array}{l}\text { Any Monthly Tax } \\
\text { Deduction (PCB) } \\
\text { in your salary } \\
\text { payslips? }\end{array}$} & Yes & 303 & 100.0 \\
\hline & No & 0 & 0.0 \\
\hline & Total & 303 & 100 \\
\hline \multirow{6}{*}{$\begin{array}{l}\text { How do you file } \\
\text { your income tax } \\
\text { forms? }\end{array}$} & Personal Computer & 160 & 52.8 \\
\hline & Manual Form & 10 & 3.3 \\
\hline & PDA/ Smartphone/ Handphone & 27 & 8.9 \\
\hline & Laptop & 106 & 35.0 \\
\hline & Never Submit Form & 0 & 0.0 \\
\hline & Total & 303 & 100 \\
\hline
\end{tabular}

Table 4

Convergent Validity

\begin{tabular}{lccc}
\hline \multicolumn{1}{c}{ Construct } & $\begin{array}{c}\text { Cronbach } \\
\text { Alpha }\end{array}$ & $\begin{array}{c}\text { Composite } \\
\text { Reliability }\end{array}$ & $\begin{array}{c}\text { Average } \\
\text { Variance } \\
\text { Extracted (AVE) }\end{array}$ \\
\hline Attitude (ATT) & 0.909 & 0.936 & 0.787 \\
General Tax Filing & 0.848 & 0.929 & 0.868 \\
Knowledge (GTFK) & 0.907 & 0.931 & 0.730 \\
Perceived Usefulness (PU) & 0.923 & 0.940 & 0.721 \\
Perceived Ease of Use & & & \\
(PEOU) & 0.933 & 0.947 & 0.749 \\
Compatibility (COMP) & 0.928 & 0.949 & 0.822 \\
Subjective Norm (SN) & 0.921 & 0.938 & 0.716 \\
Peer Influence (PI) & & & (continued) \\
\hline
\end{tabular}




\begin{tabular}{lccc}
\hline \multicolumn{1}{c}{ Construct } & $\begin{array}{c}\text { Cronbach } \\
\text { Alpha }\end{array}$ & $\begin{array}{c}\text { Composite } \\
\text { Reliability }\end{array}$ & $\begin{array}{c}\text { Average } \\
\text { Variance } \\
\text { Extracted (AVE) }\end{array}$ \\
\hline $\begin{array}{l}\text { Mass Media Referent } \\
\text { (MMR) }\end{array}$ & 0.932 & 0.945 & 0.710 \\
$\begin{array}{l}\text { Perceived Behavioural } \\
\text { Control (PBC) }\end{array}$ & 0.895 & 0.935 & 0.827 \\
$\begin{array}{l}\text { Self-Efficacy (SE) } \\
\text { Ability to Pay (ATP) }\end{array}$ & 0.898 & 0.936 & 0.831 \\
Facilitating Condition (FC) & 0.944 & 0.955 & 0.781 \\
Voluntary Tax Compliance & 0.843 & 0.895 & 0.682 \\
Intention (INT) & 0.928 & 0.954 & 0.874 \\
\hline
\end{tabular}

Most loadings have values of more than 0.40 and very close to 0.70 . Hence, the indicators were not deleted as the values of AVE and composite reliability fell within the acceptable range. For indicators outside the acceptable range, they were deleted and this constituted the deletion of 19 items, namely GTK1, GTK3, GTK5, GTK6, GTK7, GTK8, PU1, PU2, PU5, MMR7, MMR8, SE1, SE2, SE3, FC1, FC3, FC4, FC5, and FC8.

Amongst the objective of this study was to test the predictive accuracy and effect size of competing theories. The $\mathrm{R}^{2}$ was used to measure the model's predictive accuracy. As a result, the $\mathrm{R}^{2}$ values were recorded the following indicators.

Table 5

Coefficient of Determinant Values $\left(R^{2}\right)$

\begin{tabular}{lccc}
\hline Construct & TRA & TPB & DTPB \\
\hline ATT & 0.382 & 0.325 & 0.543 \\
PBC & - & 0.650 & 0.685 \\
SN & 0.633 & 0.633 & 0.626 \\
INT & 0.467 & 0.493 & 0.492 \\
\hline
\end{tabular}

As indicated in Table 5 above, the $\mathrm{R}^{2}$ values improved significantly when the constructs were multidimensional, as it provided better explanatory power. The table indicated that the construct for attitude (ATT) reported a variance of $54.3 \%$ and perceived behavioural control (PBC) had a variance of $68.5 \%$ for DTPB. This indicated that these two constructs are better explained when they are measured multi-dimensionally. As for subjective norm (SN) and intention (INT) constructs, it seemed that unidimensional constructs provided a better explanatory power (63.3\% variance for $\mathrm{SN}$ and $49.3 \%$ for 
INT in TPB). For both TRA and TPB, it can be seen that INT variance improved for $\mathrm{TPB}$ due to the inclusion of the PBC construct (49.3\% variance compared to $46.7 \%$ variance for TRA).

Furthermore, the GoF for all models had good fit for the data. As seen in Table 6 below, DTPB has a better fit compared to TRA and TPB. DTPB has the fit index of 0.707106 whereas TPB and TRA have 0.676242 and 0.523682 , respectively. This proves that DTPB is a better model to predict intentions as compared to TRA and TPB.

Table 6

Comparisons of Theories - Goodness of Fit (GoF) Indices and Explanatory Power

\begin{tabular}{lllc}
\hline & TRA & TPB & DTPB \\
\hline $\mathbf{R}^{2}$ ATT & 0.382 & 0.325 & 0.543 \\
$\mathbf{R}^{2}$ INT & 0.467 & 0.493 & 0.492 \\
$\mathbf{R}^{2}$ PBC & & 0.650 & 0.685 \\
$\mathbf{R}^{2}$ SN & 0.633 & 0.633 & 0.626 \\
\hline Average AVE & 0.554 & 0.827347 & 0.827376 \\
Total average & 1.047365 & 1.352483 & 1.414212 \\
GoF & 0.523682 & 0.676242 & 0.707106 \\
\hline
\end{tabular}

As for hypothesis testing, it would seem that TRA does not provide a clear picture or explanation beyond the acceptance of the relationship of hypothesis, whereby p-values for all hypotheses were below 0.05 . As such, TRA may not provide a clear prediction of individual voluntary tax compliance intention.

Table 7

Theory of Reasoned Action (TRA) - Path Coefficients

\begin{tabular}{lccc}
\hline Construct & $\begin{array}{c}\text { Original } \\
\text { Sample }(\boldsymbol{\beta})\end{array}$ & $\begin{array}{c}\text { T Statistics }(\mid \mathbf{O} / \\
\text { STDEV } \mid)\end{array}$ & P Values \\
\hline ATT -> INT & 0.479 & 6.457 & $\mathbf{0 . 0 0 0}$ \\
PEOU + PU + GTK +COMP -> ATT & 0.618 & 15.488 & $\mathbf{0 . 0 0 0}$ \\
PI + MMR -> SN & 0.795 & 29.920 & $\mathbf{0 . 0 0 0}$ \\
SN -> INT & 0.252 & 3.437 & $\mathbf{0 . 0 0 1}$ \\
\hline
\end{tabular}


As for hypothesis testing, the TPB model seems to provide a clearer picture or explanation due to the addition of the PBC construct into the model. In addition, all p-values for all relationships are significant except for the hypothesis of SN -> INT, which recorded the p-value $>0.05$, as seen in Table 8 below.

Table 8

Theory of Planned Behaviour (TPB) - Path coefficients

\begin{tabular}{lccc}
\hline Construct & $\begin{array}{c}\text { Original } \\
\text { Sample } \\
(\mathbf{O})\end{array}$ & $\begin{array}{c}\text { T Statistics } \\
(\mid \text { O/STDEV })\end{array}$ & P Values \\
\hline ATP + SE + FC -> PBC & 0.806 & 25.465 & $\mathbf{0 . 0 0 0}$ \\
ATT -> INT & 0.382 & 4.129 & $\mathbf{0 . 0 0 0}$ \\
GTK + PEOU + PU + COMP -> ATT & 0.528 & 11.204 & $\mathbf{0 . 0 0 0}$ \\
PBC -> INT & 0.260 & 2.593 & $\mathbf{0 . 0 1 0}$ \\
PI + MMR -> SN & 0.795 & 29.605 & $\mathbf{0 . 0 0 0}$ \\
SN -> INT & 0.130 & 1.507 & $\mathbf{0 . 1 3 3}$ \\
\hline
\end{tabular}

DTPB on the other hand provides a clearer explanation of the hypotheses of relationships. This clearer explanation is only possible because of the decomposition of the construct into multi-dimensional measures for the main constructs-ATT, SN and PBC. As seen in Table 9 below, the hypotheses for COMP $->$ ATT, PEOU $->$ ATT, $\mathrm{SE}->\mathrm{PBC}$, and SN -> INT were not significant because of the p-values $>0.05$. These results indicated a better explanation of the types of factors that actually play a role in influencing individual voluntary tax compliance intention.

Table 9

Decomposed Theory of Planned Behaviour (DTPB) - Path Coefficients

\begin{tabular}{lccc}
\hline \multicolumn{1}{c}{ Construct } & $\begin{array}{c}\text { Original } \\
\text { Sample }(\mathbf{O})\end{array}$ & $\begin{array}{c}\text { T Statistics } \\
(\mid \mathbf{O} / \text { STDEV } \mid)\end{array}$ & P Values \\
\hline ATP -> PBC & 0.202 & 2.003 & $\mathbf{0 . 0 4 6}$ \\
ATT -> INT & 0.380 & 4.411 & $\mathbf{0 . 0 0 0}$ \\
COMP -> ATT & 0.056 & 0.921 & $\mathbf{0 . 3 5 7}$ \\
FC -> PBC & 0.577 & 6.264 & $\mathbf{0 . 0 0 0}$ \\
GTK -> ATT & 0.435 & 5.879 & $\mathbf{0 . 0 0 0}$ \\
MMR -> SN & 0.461 & 6.252 & $\mathbf{0 . 0 0 0}$ \\
PBC -> INT & 0.260 & 2.504 & $\mathbf{0 . 0 1 3}$ \\
\hline
\end{tabular}




\begin{tabular}{lccc}
\hline \multicolumn{1}{c}{ Construct } & $\begin{array}{c}\text { Original } \\
\text { Sample }(\mathbf{O})\end{array}$ & $\begin{array}{c}\text { T Statistics } \\
(\mid \text { O/STDEV } \mid)\end{array}$ & P Values \\
\hline PEOU $>$ ATT & -0.023 & 0.414 & $\mathbf{0 . 6 7 9}$ \\
\hline PI $>$ SN & 0.378 & 5.169 & $\mathbf{0 . 0 0 0}$ \\
\hline PU $>$ ATT & 0.344 & 4.383 & $\mathbf{0 . 0 0 0}$ \\
\hline SE $>$ PBC & 0.097 & 1.550 & $\mathbf{0 . 1 2 2}$ \\
\hline SN $>$ INT & 0.131 & 1.545 & $\mathbf{0 . 1 2 3}$ \\
\hline
\end{tabular}

\subsection{Discussion and Conclusion}

The main purpose of this study was two-fold. Firstly, the main objective was to compare competing theories of intention in tax compliance settings. The purpose of comparing competing theories was to ascertain which of these theories provided better predictiveness and explanation for tax compliance intention. As indicated, the decomposition of main constructs into multi-dimension items provided better explanation and predictiveness of variables that influence individuals. The second objective was to ascertain if the items used in the data fit the constructs for the study. This was established with the use of GoF, and it was observed that DTPB was most fitting. These findings also provided some managerial implications.

As indicated in the path analysis for DTPB, the hypotheses for COMP -> ATT and PEOU $\rightarrow$ ATT relationships were not supported. This indicated that for attitudinal constructs, respondents felt that by filing income tax via e-filing platform, they are satisfied by the fast service provided as they were already aware of the implications of filing their taxes. The respondents were of the opinion that e-filing facilities should be more user friendly and compatible in order to facilitate and increase their satisfaction of the service provided. As such, it is recommended that IRB should relook at the userfriendliness of their site in order to encourage more individuals to file their taxes via e-filing.

Another implication of this study is that individuals felt that the important people in their lives did not play a significant role in influencing them to file their taxes. However, interestingly the respondents acknowledged the use of mass media as reference to obtain information regarding income tax form submission. This could be an indication that, with the advancement of technologies, taxpayers may opt to use mass media. Also, filing of taxes via e-filing does not require self-confidence (self-efficacy) as a constraint to filing taxes via e-filing. Moreover, the majority of respondents only required very basic income tax form filing knowledge. Apart from very basic understanding of income tax form filing processes, most respondents just do not understand the tax laws 
or changes of tax laws, and their requirements. Taxpayers may opt for mass media as referents in obtaining relevant information, either as a reminder or informatively based on comments and highlights posted on mass media. However, in times of economic uncertainties or financial crisis, many would opt for deferment in tax payments. Since the e-filing system provides the advantage of filling and computing prior to declaration of tax liabilities, the amount of possible tax liabilities would detract taxpayers from filing their income tax forms immediately. Though taxpayers may acknowledge their tax liabilities, their ability to pay may cause deferment in income tax form submissions or worst still, tax evasion. Hence, taxpayers' ability to pay taxes prior to income tax form submission plays an important role toward voluntary compliance.

This study only focused on the employment income taxpayers. Future studies could utilise the DTPB model in providing better understanding and explanation toward tax compliance behaviour of other groups. In addition, cluster sampling could be used to understand each group of intended study. Future study could compare the behaviour of public and private sectors, gender-based behaviours, as well as between urban and suburban taxpayers. In conclusion, the DTPB model can be flexible, provide better explanation, and easy to understand as well as have better predictiveness which is applicable throughout various fields of studies.

\section{Acknowledgement}

The authors would like to thank the supervisors, UUM lecturers and anonymous reviewers of Journal of Management Business and Accounting (JMBA). The authors would also like to give special thanks to the Institute for Management \& Business Research (IMBRe) - UUM for the opportunity towards the publication of this article. Special appreciation also extended to all related parties involved in the research study.

\section{References}

Ajzen, I. (1991). The Theory of Planned Behavior. Organizational Behavior and Human Decision Processes, 50, 179-211.

Ajzen, I. (2001). Nature and Operation of Attitudes. Annual Review of Psychology, 52, 27-58.

Ajzen, I., \& Fishbein, M. (1980). Understanding attitudes and predicting social behavior. Englewood Cliffs, NJ: Prentice-Hall.

Bagozzi, R. P., Wong, N., Abe, S., \& Bergami, M. (2000). Cultural and situational contingencies and the theory of reasoned action: Application to fast food restaurant consumption. Journal of Consumer Psychology, 9(2), 97-106. https:// doi.org/10.1207/S15327663JCP0902 
Bandura, A. (1986). Social foundations of thought and action: A social-cognitive view. Englewood Cliffs, NJ: Prentice Hall.

Bhattacherjee, A. (2000). Acceptance of E-commerce services: The case of electronic brokerages. IEEE Transactions on Systems, Man, and Cybernetics Part A: Systems and Humans., 30(4), 411-420. https://doi.org/10.1109/3468.852435.

Bidin, Z., \& Md Idris, K. (2009). Sikap, norma subjektif dan kawalan gelagat ditanggap terhadap niat gelagat kepatuhan zakat pendapatan gaji. International Journal of Management Studies, 16(1), 31-55. Retrieved from http://repo.uum.edu.my/3/1/ ijms1612.pdf

Bidin, Z., \& Mohd Shamsudin, F. (2013). Using theory of reasoned action to explain taxpayer intention to comply with Goods and Services Tax ( GST ) School of Accounting, College of Business, Othman Yeop Abdullah Graduate School of Business. Middle-East Journal of Scientific Research, 17(3), 387-394. https:// doi.org/10.5829/idosi.mejsr.2013.17.03.12167

Chau, P. Y. K., \& Hu, P. J.-H. (2001). Information technology acceptance by individual professionals: A model comparison approach. Decision Sciences, 32(4), 699719.

Choong, K. F., \& Wong, E. S. K. (2011). A study on self-assessment tax system awareness in Malaysia. Australian Journal of Basic and Applied Sciences, 5(7), 881-888. Retrieved from http://ajbasweb.com/old/ajbas/2011/July-2011/881888.pdf

Doane, A. N., Kelley, M. L., \& Pearson, M. R. (2016). Reducing cyberbullying: A theory of reasoned action-based video prevention program for college students. Aggressive Behavior, 42, 136-146. https://doi.org/10.1002/ab.21610

Doane, A. N., Pearson, M. R., \& Kelley, M. L. (2014). Predictors of cyberbullying perpetration among college students: An application of the theory of reasoned action. Computers in Human Behavior, 36, 154-162.

Fishbein, M., \& Ajzen, I. (1975). Belief Attitude, Intention and Behavior. An Introduction to Theory and Research. Reading, Massachusetts: Addison-Wesley Publishing Company.

Fisher, W. A., Fisher, J. D., \& Rye, B. J. (1995). Understanding and promoting AIDS-preventive behavior: Insights from the theory of reasoned action. Health Psychology, 14(3), 255-264.

Fitzmaurice, J. (2005). Incorporating Consumers' Motivations into the Theory of Reasoned Action. Psychology \& Marketing, 22(11), 911-929. https://doi. org/10.1002/mar.20090

Gillmore, M. R., Archibald, M. E., Morrison, D. M., Wilsdon, A., Wells, E. A., Hoppe, M. J., Murowchick, E. (2002). Teen sexual behavior: Applicability of the theory of reasoned action. Journal of Marriage and Family, 64(4), 885-897.

Goldenhar, L. M., \& Connell, C. M. (1992). Understanding and predicting recycling behavior: an application of the theory of reasoned action. Journal of Environmental Systems, 22(1), 91-103. https://doi.org/10.2190/92KU-NXLT-XC32-RHD6

Ha, C. L. (1998). The theory of reasoned action applied to brand loyalty. Journal of Product \& Brand Management, 7(1), 51-61. 
Harrison, K. (2009). The Multidimensional Media Influence Scale: Confirmatory factor structure and relationship with body dissatisfaction among African American and Anglo American children. Body Image, 6(3), 207-215. https://doi.org/10.1016/j. bodyim.2009.04.001

Hastuti, S., Suryaningrum, D. H., Susilowati, L., \& Muchtolifah. (2014). Implementation of decomposed theory of planned behavior on the adoption of e-filling systems taxation policy in Indonesia. Expert Journal of Business and Management, 2, $1-8$.

Hite, P. A. (1997). An investigation of moral suasion and vertical equity arguments on intended taxpayer noncompliance. Law and Policy, 19(1), 1-22. https://doi. org/10.1111/1467-9930.00019

Hsu, M.-H., \& Chiu, C.-M. (2004a). Internet self-efficacy and electronic service acceptance. Decision Support Systems, 38, 369-381. https://doi.org/10.1016/j. dss.2003.08.001

Hsu, M.-H., \& Chiu, C.-M. (2004b). Predicting electronic service continuance with a decomposed theory of planned behaviour. Behaviour \& Information Technology, 23(5), 359-373. https://doi.org/10.1080/01449290410001669969

Huang, E., \& Chuang, M. H. (2007). Extending the theory of planned behaviour as a model to explain post-merger employee behaviour of IS use. Computers in Human Behavior, 23, 240-257. https://doi.org/10.1016/j.chb.2004.10.010

Hung, S.-Y., Chang, C.-M., \& Yu, T.-J. (2006). Determinants of user acceptance of the e-Government services: The case of online tax filing and payment system. Government Information Quarterly, 23(1), 97-122. https://doi.org/10.1016/j. giq.2005.11.005

IRBM, (2013). Tax Investigation Framework - Effective 1 October 2013.

IRBM, (2018). Annual Report 2017. Kuala Lumpur.

James, S., \& Alley, C. (2004). Tax Compliance, Self-Assessment and Tax Administration. Journal of Finance and Management in Public Services, 2(2), 27-42.

Kang, H., Hahn, M., Fortin, D. R., Hyun, Y. J., \& Eom, Y. (2006). Effects of Perceived Behavioral Control on the Consumer Usage Intention of E-coupons. Psychology \& Marketing, 23(10), 841-864. https://doi.org/10.1002/mar

Kashima, Y., Gallois, C., \& McCamish, M. (1993). The theory of reasoned action and cooperative behaviour: It takes two to use a condom. British Journal of Social Psychology, 32, 227-239.

Khalil, M. N. (2005). An empirical study of internet banking acceptance in Malaysia: an extended decomposed theory of planned behaviour. Southern Illinois University, Carbondale.

Lau, A. S. M. (2004). Strategies to encourage the adoption of G2C e-government services in Hong Kong. Electronic Government, 1(3), 273-292.

Liker, J. K., \& Sindi, A. A. (1997). User acceptance of expert systems: a test of the theory of reasoned action. Journal of Engineering and Technology Management, 14(2), 147-173. 
Lindhjem, H., \& Navrud, S. (2011). Are Internet surveys an alternative to face-to-face interviews in contingent valuation? Ecological Economics, 70(9), 1628-1637. https://doi.org/10.1016/j.ecolecon.2011.04.002

Loo, E. C., Evans, C., \& Mckerchar, M. (2010). Challenges in Understanding Compliance Behaviour of Taxpayers in Malaysia. Asian Journal of Business and Accounting, 3(2), 101-118.

Mathieson, K. (1991). Predicting User Intentions: Comparing the Technology Acceptance Model with the Theory of Planned Behavior. Information Systems Research, 2(3), 173-191.

Mckerchar, M. (2008). Philosophical Paradigms, Inquiry Strategies and Knowledge Claims: Applying the Principles of Research Design and Conduct to Taxation. EJournal of Tax Research, 6(1), 5-22.

Md Husin, M., \& Ab Rahman, A. (2016). Predicting intention to participate in family takaful scheme using Decomposed Theory of Planned Behaviour. International Journal of Social Economics, 43(12). https://doi.org/10.1177/0020764008093373

Md Husin, M., Ismail, N., \& Ab Rahman, A. (2016). The roles of mass media, word of mouth and subjective norm in family takaful purchase intention. Journal of Islamic Marketing, 7(1). https://doi.org/10.1108/JIMA-03-2015-0020

Mishra, D., Akman, I., \& Mishra, A. (2014). Theory of Reasoned Action application for Green Information Technology acceptance. Computers in Human Behavior, 36, 29-40. https://doi.org/10.1016/j.chb.2014.03.030

Mohd Tallaha, A., Abdul Shukor, Z., \& Abu Hassan, N. S. (2014). Factors influencing e-filing usage among Malaysian taxpayers: Does tax knowledge matters? Jurnal Pengurusan, 40, 91-101. https://doi.org/10.17576/pengurusan-2014-40-08

Mohdali, R., \& Pope, J. (2012). The effects of religiosity and external environment on voluntary tax compliance. New Zealand Journal of Taxation Law and Policy, 18(June), 119-139.

Oh, T. H., \& Lim, M. S. (2011). Intention of tax non-compliance-examine the gaps. International Journal of Business and Social Science, 2(7), 79.

Okello, A. (2014). Managing income tax compliance through self-assessment. IMF Working Paper, 41(March), 4-32.

Ramayah, T., Mohd. Yusoff, Y., Jamaludin, N., \& Ibrahim, A. (2009). Applying the theory of planned behavior (TPB) to predict internet tax filing intentions. International Journal of Management, 26(2), 272-284.

Sax, L. J., Gilmartin, S. K., \& Bryant, A. N. (2003). Assessing Response Rates and Nonresponse Bias in Web And Paper Surveys. Research in Higher Education, 44(4), 409-432.

Shimp, T. A., \& Kavas, A. (1984). The theory of reasoned action applied to coupon usage. Journal of Consumer Research, 11(3), 795-809.

Tao, C. C., \& Fan, C. C. (2017). A modified decomposed theory of planned behaviour model to analyze user intention towards distance-based electronic toll collection 
services. Promet-Traffic \&Transportation, 29(1), 85-97. https://doi.org/10.7307/ ptt.v29i1.2076

Taylor, S., \& Todd, P. A. (1995a). Decomposition and crossover effects in the theory of planned behavior: A study of consumer adoption intentions. International Journal of Research in Marketing, 12(2), 137-155.

Taylor, S., \& Todd, P. A. (1995b). Understanding information technology usage: A test of competing models. Information Systems Research, 6(2), 144-176. https://doi. org/10.1287/isre.6.2.144

Venkatesh, V., Chan, F. K. Y., \& Thong, J. Y. L. (2012). Designing e-government services: Key service attributes and citizens' preference structures. Journal of Operations Management, 30(1-2), 116-133. https://doi.org/10.1016/j. jom.2011.10.001

Venkatesh, V., Morris, M. G., Davis, G. B., \& Davis, F. D. (2003). User Acceptance of Information Technology: Toward a Unified View. MIS Quarterly, 27(3), 425478.

Wartick, M. L., \& Rupert, T. J. (2010). The effects of observing a peer's likelihood of reporting income on tax reporting decisions. Advances in Taxation, 19, 65-94. https://doi.org/10.1108/S1058-7497(2010)0000019005

Woolley, D. J. (2015). Two issues to consider in digital piracy research: The use of Likert-like questions and the theory of reasoned action in behavioral surveys. Journal of Legal, Ethical and Regulatory Issues, 18(3), 63-68. 
Appendix A: Questionnaire items

\section{General tax filing knowledge}

\begin{tabular}{|c|l|}
\hline 1 & It is a criminal offence for not submitting income tax form. \\
\hline 2 & $\begin{array}{l}\text { E-filing system is an electronic mode of filing income tax form through } \\
\text { internet. }\end{array}$ \\
\hline 3 & I must provide the latest information of my particulars in the e-filing system. \\
\hline 4 & $\begin{array}{l}\text { I know that I already submitted my electronic income tax form when I } \\
\text { receive an electronic confirmation of receipt from IRBM on the computer } \\
\text { screen. }\end{array}$ \\
\hline 5 & $\begin{array}{l}\text { IRBM provides an option to amend my income tax form if I find mistakes in } \\
\text { my earlier e-filing submission. }\end{array}$ \\
\hline 6 & $\begin{array}{l}\text { My employers already deducted Monthly Tax Deduction (MTD) from my } \\
\text { monthly salary, so I do not need to submit my income tax form every year. }\end{array}$ \\
\hline 7 & I do not need to submit income tax form if I elect MTD as final tax. \\
\hline 8 & $\begin{array}{l}\text { As I already paid my taxes, I do not need to submit my income tax form } \\
\text { voluntarily. }\end{array}$ \\
\hline
\end{tabular}

Perceived ease of use

\begin{tabular}{|c|l|}
\hline 1 & $\begin{array}{l}\text { Learning to submit income tax form voluntarily by operating e-filing system would } \\
\text { be easy for me. }\end{array}$ \\
\hline 2 & $\begin{array}{l}\text { I would find it easy to submit income tax form voluntarily by getting e-filing system } \\
\text { to do what I want it to do. }\end{array}$ \\
\hline 3 & $\begin{array}{l}\text { My interaction with e-filing system would be clear and understandable for me to file } \\
\text { income tax form voluntarily. }\end{array}$ \\
\hline 4 & $\begin{array}{l}\text { I would find e-filing system to be flexible to interact with during the process of } \\
\text { voluntary income tax form submission. }\end{array}$ \\
\hline 5 & $\begin{array}{l}\text { It would be easy for me to become skilful to submit income tax form voluntarily by } \\
\text { using e-filing system. }\end{array}$ \\
\hline 6 & $\begin{array}{l}\text { I would find the submission of income tax form voluntarily through e-filing system } \\
\text { easy to use. }\end{array}$ \\
\hline
\end{tabular}

\section{Perceived Usefulness}

\begin{tabular}{|c|l|}
\hline 1 & $\begin{array}{l}\text { Voluntary compliance with tax law using e-filing system will be of no } \\
\text { benefit to me. }\end{array}$ \\
\hline 2 & $\begin{array}{l}\text { Using e-filing system to comply with tax laws voluntarily will improve my } \\
\text { performance in submitting income tax form. }\end{array}$ \\
\hline 3 & $\begin{array}{l}\text { The advantages of filing income tax form voluntarily using e-filing system } \\
\text { will outweigh the disadvantages. }\end{array}$ \\
\hline
\end{tabular}




\begin{tabular}{|c|l|}
\hline 4 & $\begin{array}{l}\text { Overall, submission of income tax form voluntarily using the e-filing system } \\
\text { will be advantageous. }\end{array}$ \\
\hline 5 & $\begin{array}{l}\text { Voluntary submission of income tax form using e-filing system that does not } \\
\text { benefit to me is bad. }\end{array}$ \\
\hline 6 & $\begin{array}{l}\text { Voluntary submission of income tax form using e-filing system that will } \\
\text { improve my tax compliance is good. }\end{array}$ \\
\hline 7 & $\begin{array}{l}\text { The voluntary submission of income tax form using e-filing system service } \\
\text { with more advantageous than disadvantageous is good. }\end{array}$ \\
\hline 8 & $\begin{array}{l}\text { The voluntary submission of income tax form using e-filing system service } \\
\text { that is advantageous is good. }\end{array}$ \\
\hline
\end{tabular}

\section{Compatibility}

\begin{tabular}{|c|l|}
\hline 1 & $\begin{array}{l}\text { Using the e-filing system will fit me well with the way I work in submitting } \\
\text { my income tax form voluntarily. }\end{array}$ \\
\hline 2 & $\begin{array}{l}\text { Using the e-filing system will fit into my workstyle in submitting my income } \\
\text { tax form voluntarily. }\end{array}$ \\
\hline 3 & $\begin{array}{l}\text { The setup of the e-filing system will be compatible with the way I work in } \\
\text { submitting my income tax form voluntarily. }\end{array}$ \\
\hline 4 & $\begin{array}{l}\text { E-filing system service that fits well the way I work is good towards } \\
\text { voluntary tax compliance. }\end{array}$ \\
\hline 5 & $\begin{array}{l}\text { E-filing system service that fits into my workstyle is good towards voluntary } \\
\text { tax compliance. }\end{array}$ \\
\hline 6 & $\begin{array}{l}\text { E-filing system service that is compatible with the way I work is good } \\
\text { towards voluntary tax compliance. }\end{array}$ \\
\hline
\end{tabular}

\section{Attitude}

\begin{tabular}{|c|l|}
\hline 1 & $\begin{array}{l}\text { With my general tax filing knowledge, voluntary tax compliance using } \\
\text { e-filing system is a good idea. }\end{array}$ \\
\hline 2 & $\begin{array}{l}\text { With my general tax filing knowledge, voluntary tax compliance using } \\
\text { e-filing system is a wise idea. }\end{array}$ \\
\hline 3 & $\begin{array}{l}\text { With my general tax filing knowledge, I like the idea of voluntary tax } \\
\text { compliance via e-filing system. }\end{array}$ \\
\hline 4 & $\begin{array}{l}\text { With my general tax filing knowledge, voluntary tax compliance via e-filing } \\
\text { system would be pleasant. }\end{array}$ \\
\hline
\end{tabular}




\section{Peer Influence}

\begin{tabular}{|c|l|}
\hline 1 & $\begin{array}{l}\text { My friends would think that I should voluntarily comply with tax laws by } \\
\text { submitting my income tax form via e-filing system. }\end{array}$ \\
\hline 2 & $\begin{array}{l}\text { My colleagues would think that I should voluntarily comply with tax laws by } \\
\text { submitting my income tax form via e-filing system. }\end{array}$ \\
\hline 3 & $\begin{array}{l}\text { My family would think that I should voluntarily comply with tax laws by } \\
\text { submitting income tax form via e-filing. }\end{array}$ \\
\hline 4 & $\begin{array}{l}\text { Generally speaking, I want to do what my family think I should do towards } \\
\text { voluntary tax compliance in submitting income tax form via e-filing system. }\end{array}$ \\
\hline 5 & $\begin{array}{l}\text { Generally speaking, I want to do what my friends think I should do towards } \\
\text { voluntary tax compliance submitting income tax form via e-filing system. }\end{array}$ \\
\hline 6 & $\begin{array}{l}\text { Generally speaking, I want to do what my colleagues think I should do } \\
\text { towards voluntary tax compliance in submitting income tax form via e-filing } \\
\text { system. }\end{array}$ \\
\hline
\end{tabular}

\section{Mass Media Referent}

\begin{tabular}{|c|l|}
\hline 1 & $\begin{array}{l}\text { I read/saw news/reports that having to file income tax forms voluntarily via } \\
\text { e-filing system is a good way to voluntarily declare my income tax. }\end{array}$ \\
\hline 2 & $\begin{array}{l}\text { The media and advertising consistently recommend the usage of e-filing } \\
\text { system to comply in filing income tax forms voluntarily. }\end{array}$ \\
\hline 3 & $\begin{array}{l}\text { In my profession, it is advisable to comply by voluntarily filing the income } \\
\text { tax form. }\end{array}$ \\
\hline 4 & $\begin{array}{l}\text { The media are full of reports, articles and news suggesting that using e-filing } \\
\text { system to comply voluntarily is a good idea. }\end{array}$ \\
\hline 5 & $\begin{array}{l}\text { Mass media reminds me of the last income tax filing date in complying } \\
\text { voluntarily with tax laws. }\end{array}$ \\
\hline 6 & $\begin{array}{l}\text { I am able to search for information and answers regarding income tax filing } \\
\text { issues via internet or social media as referent. }\end{array}$ \\
\hline 7 & $\begin{array}{l}\text { I learn how to submit my income tax form towards voluntary tax compliance } \\
\text { by using my idols guidance in mass media. }\end{array}$ \\
\hline 8 & I would like my voluntary tax compliance behaviour to look like my idols. \\
\hline 9 & $\begin{array}{l}\text { Watching TV, listening to radio; or reading magazines or social media posts } \\
\text { makes me want to comply voluntarily with tax laws via e-filing system. }\end{array}$ \\
\hline
\end{tabular}

\section{Subjective Norm}




\begin{tabular}{|c|l|}
\hline 2 & $\begin{array}{l}\text { People who are important to me would think I should voluntarily comply } \\
\text { with tax laws in submitting income tax form via e-filing system. }\end{array}$ \\
\hline 3 & $\begin{array}{l}\text { People who influence my behaviour would think that I should voluntarily } \\
\text { comply with tax laws in submitting my income tax form via e-filing system. }\end{array}$ \\
\hline 4 & $\begin{array}{l}\text { People who are important to me would think I should submit my income tax } \\
\text { form voluntarily via e-filing system. }\end{array}$ \\
\hline
\end{tabular}

\begin{tabular}{|c|l|}
\hline \multicolumn{2}{|l}{ Self-Efficacy } \\
\hline 1 & $\begin{array}{l}\text { I would feel comfortable to submit income tax form voluntarily using e-filing } \\
\text { system. }\end{array}$ \\
\hline 2 & $\begin{array}{l}\text { If I want to, I could easily operate e-filing system voluntarily on my own to } \\
\text { submit my income tax form. }\end{array}$ \\
\hline 3 & $\begin{array}{l}\text { I would be able to submit income tax form voluntarily using e-filing system } \\
\text { even if there is no one around to show me how to use it. }\end{array}$ \\
\hline 4 & $\begin{array}{l}\text { For me, feeling comfortable submitting income tax form by using e-filing } \\
\text { system on my own is important. }\end{array}$ \\
\hline 5 & $\begin{array}{l}\text { For me, being able to easily operate the e-filing system to file income tax } \\
\text { form voluntarily on my own is important. }\end{array}$ \\
\hline 6 & $\begin{array}{l}\text { For me, being able to submit income tax form by using e-filing system even } \\
\text { if there was no one around to show me how to use it is important. }\end{array}$ \\
\hline
\end{tabular}

\section{Facilitating Conditions}

\begin{tabular}{|c|l|}
\hline 1 & $\begin{array}{l}\text { The equipment (printer/computer) in e-filing system is not compatible with } \\
\text { other computers that I used for me to submit income tax form voluntarily. }\end{array}$ \\
\hline 2 & $\begin{array}{l}\text { The e-filing system is not compatible with other software systems I use to } \\
\text { submit my income tax form voluntarily. }\end{array}$ \\
\hline 3 & $\begin{array}{l}\text { I will have trouble in submitting income tax form voluntarily through e-filing } \\
\text { system. }\end{array}$ \\
\hline 4 & $\begin{array}{l}\text { For me, having e-filing service equipment that is compatible with other } \\
\text { equipment that I use is important for the voluntarily submission of income } \\
\text { tax form. }\end{array}$ \\
\hline 5 & $\begin{array}{l}\text { For me, having e-filing service software that is compatible with the software } \\
\text { I use is important in the submission of income tax form voluntarily. }\end{array}$ \\
\hline 6 & $\begin{array}{l}\text { For me, whether or not I have trouble in using e-filing to submit my income } \\
\text { tax form voluntarily is important. }\end{array}$ \\
\hline 7 & $\begin{array}{l}\text { I expect to get the help I need in using e-filing system to submit income tax } \\
\text { form voluntarily. }\end{array}$ \\
\hline
\end{tabular}




\begin{tabular}{|c|l|}
\hline 8 & $\begin{array}{l}\text { It would be easy for me to get assistance when I am having trouble using } \\
\text { e-filing system to submit income tax form voluntarily. }\end{array}$ \\
\hline 9 & $\begin{array}{l}\text { I expect clear instructions for using e-filing system in submitting income tax } \\
\text { form voluntarily to be available to me. }\end{array}$ \\
\hline
\end{tabular}

\begin{tabular}{|c|l|} 
Ability to Pay \\
\begin{tabular}{|c|l|}
\hline 1 & $\begin{array}{l}\text { I can perform my tasks efficiently including paying tax after voluntarily } \\
\text { declaring my income tax. }\end{array}$ \\
\hline 2 & $\begin{array}{l}\text { I am able to pay tax even there is an obstacle after voluntarily declaring my } \\
\text { income tax. }\end{array}$ \\
\hline 3 & $\begin{array}{l}\text { Even though facing with financial difficulties, I am still able to pay tax after } \\
\text { voluntarily declaring my income tax every year. }\end{array}$ \\
\hline 4 & $\begin{array}{l}\text { I am able to pay tax after voluntarily declaring my income tax because I paid } \\
\text { income taxes before. }\end{array}$ \\
\hline 5 & $\begin{array}{l}\text { I am able to achieve all my objectives including paying tax after voluntarily } \\
\text { declaring my income tax. }\end{array}$ \\
\hline 6 & $\begin{array}{l}\text { I might need to defer tax payment through instalments when facing } \\
\text { worst financial difficulties during the decision to declare my income tax } \\
\text { voluntarily. }\end{array}$ \\
\hline
\end{tabular}
\end{tabular}

\section{Perceived Behavioural Control}

\begin{tabular}{|c|l|}
\hline 1 & $\begin{array}{l}\text { I would be able to submit income form voluntarily by using the e-filing } \\
\text { system. }\end{array}$ \\
\hline 2 & $\begin{array}{l}\text { Using the e-filing system to submit income tax form voluntarily is entirely } \\
\text { within my control. }\end{array}$ \\
\hline 3 & $\begin{array}{l}\text { I have the resources and the knowledge and the ability to submit my income } \\
\text { tax form voluntarily by making use of the e-filing system. }\end{array}$ \\
\hline
\end{tabular}

\section{Voluntary Tax Compliance Intention}

\begin{tabular}{|c|l|}
\hline 1 & I intend to comply voluntarily with income tax law via e-filing system. \\
\hline 2 & $\begin{array}{l}\text { I intend to comply voluntarily with income tax law via e-filing system by } \\
\text { next income tax filing due date. }\end{array}$ \\
\hline 3 & $\begin{array}{l}\text { I intend to comply voluntarily with income tax law frequently via e-filing } \\
\text { system. }\end{array}$ \\
\hline
\end{tabular}

